\title{
DIGITAL INTERACTIVE EXPERIENCES IN CONTEMPORARY ART MUSEUMS
}

\author{
Gamze KARAYILANOĞLU \\ Mimar Sinan Fine Arts University, Turkey \\ gamze.karayilanoglu@msgsu.edu.tr \\ https://orcid.org/0000-0002-7874-4902 \\ Burçin Cem ARABACIOĞLU \\ Mimar Sinan Fine Arts University, Turkey \\ burcin.arabacioglu@msgsu.edu.tr \\ https://orcid.org/0000-0002-1204-4479
}

\begin{abstract}
As a result of a series of technological developments in the 21 st century, the production and consumption of cultural and artistic activities have simultaneously transformed. Art museums are pioneering public and institutions that use contemporary methods to provide an effective museum experience in the transfer of culture and display of artworks. With this study, it is aimed to examine the digital technological applications used in contemporary art museums by focusing the museum experience. In this research, the concept of experience and the development process of digital interactive technologies have been determined by literature review through printed publications and online sources. Furthermore, a series of field researches were conducted at several contemporary art museums that use digital interactive technologies. In light of the data obtained, digital interactive technologies were identified as; touch screens, digital audio systems, projection mapping, quick response codes, virtual reality, augmented reality, mixed reality, and artificial intelligence. As a result of this study, suggestions were made to increase the experience in contemporary art museums with digital interactive technologies.
\end{abstract}

Keywords: Contemporary Art Museums, Digital Interactive Technologies, Museum Experience, Augmented Reality, Mixed Reality

\section{ÇAĞDAŞ SANAT MÜZELERİNDE DİJiTAL ETKILEŞİMLI TEKNOLOJILER}

\section{$\ddot{O} \mathbf{Z}$}

21. Yüzyll'da gerçekleşen bir dizi teknolojik gelişme ile birlikte kültür-sanat etkinliklerinin üretim ve tüketim şekilleri de eşzamanlı olarak dönüşmektedir. Sanat müzeleri; kültürün aktarımı ve sanat eserlerinin sergilenmesinde ziyaretçilerine etkin bir müze deneyimi sunma amacıyla çağdaş yöntemleri kullanan öncü kamusal ve kurumsal mekanlardır. Bu çalışma, çağdaş sanat müzelerinde kullanılan dijital teknolojik uygulamaları müze deneyimi odağında irdelemeyi amaçlamaktadır. Araştırmada deneyim kavramı ve dijital etkileşimli teknolojilerin gelişim süreci literatürdeki temel kaynak ve verilerin taranması ile tespit edilmiş, çağdaş sanat müzelerinde kullanılan dijital etkileşimli teknolojiler saha araştırmaları, basılı yayınlar ve çevrimiçi kaynaklar üzerinden incelenmiştir. Elde edilen veriler sşı̆̆ında tespit edilen dijital etkileşimli teknolojiler; dokunmatik ekranlar, dijital ses sistemleri, projeksiyon haritalama, kare kod uygulamaları, sanal gerçeklik, artııılmış gerçeklik, karma gerçeklik ve yapay zeka teknolojileri olarak belirlenmiş, tarihsel gelişimleri ve çağdaş sanat

Research Article - This article was checked by iThenticate

Copyright (C) The Turkish Online Journal of Design, Art and Communication 
müzelerinde kullanım alanları üzerinden örneklerle incelenmiştir. Çalışma sonucunda dijital etkileşimli teknolojilerle çağdaş sanat müzelerinde deneyimi artırmaya yönelik öneriler getirilmiştir.

Anahtar Kelimeler: Çağdaş Sanat Müzeleri, Dijital Etkileşimli Teknolojiler, Müze Deneyimi, Artırılmış Gerçeklik, Karma Gerçeklik

\section{INTRODUCTION}

Concepts such as easy access to information and digital interactive experiences have emerged with new communication technologies in the $21^{\text {st }}$ Century. Along with these new social and technological developments, museum structures have also been transformed from 'ritual' spaces to 'experience' spaces. This transformation is experienced not only in museum structures but also in administrative and social manifesto of contemporary museums. Institutionalized museums began to use digital communication technologies such as social media accounts, smartphone applications and virtual museum tours etc. Along with the architectural experience of museums, it is now possible to have different spatial experiences at each visit with the rise of new media art and digital technological exhibition methods.

One of the main subjects of museology is to display artworks efficiently. In this context, curators and museum directors develop different forms of exhibitions in consideration of the theme, content and the target audience. Selected exhibition methods should allow visitors to interact with artworks by using multiple senses at the same time to create a satisfying museum experience. To provide a multisensory environment, museum collections can be supported with devices and applications such as moving visuals, digital sounds, interactive sources of information, mechanical-electronic models and lighting devices. It is observed that complementary visual technologies such as haptic interfaces, augmented (AR), artificial (VR) reality and 3D prototype production methods are integrated into museums (Di Giuseppantonio et al. 2015).

There is a rich literature on museum experience (Adams, Falk \& Dierking, 2003; Black \& Hein, 2003; Falk \& Dierking, 1992, 2000, 2012; Hooper-Greenhill, 1999; Black, 2012). In his book Art as Experience, John Dewey, who influenced contemporary museology in the field of educational theory and practices, suggests comprehensive theories for artistic and aesthetic experience (Bedford 2014). Perception and experience issues were examined by museum researchers such as Falk, J., Dierking, D., Hooper-Greenhill, E., Black, G. Contemporary museums aim to be inclusive and offer experiences that appeal to all ages. These experiences can be educational programs, workshops, exhibitions, and events for all ages. In her study "Museums and Education" Hooper-Greenhill (2007) examined the educational role of museums through surveys on student and teacher groups. Hooper-Greenhill (2000) suggests that museums have an effective role in transferring information by providing hands-on access to educational materials and "real" objects.

Falk and Dierking created a museum experience model called 'contextual model of learning' in their studies 'The Museum Experience' (1992) and 'The Museum Experience Revisited' (2012). They focused on the concept of experience by considering the museum experience under three stages as before, during and after the visits. As a result of the study, they pointed out the developments of technology-oriented experiences in museums are increasing and emphasized that the relations between museums and citizens are becoming more transparent progressively.

Black (2012) states that museums should meet the needs of the entertainment-oriented visitors of the digital age while simultaneously bring them together with the museum collections. He defines the $21^{\text {st }}$ century museum experience holistically with museum collections, documentation, and museum space as well as tangible (exhibition systems, digital technologies, etc.) and intangible (inclusiveness, responding to user needs, etc.) elements and supportive cultural elements.

Supported by the related studies on museum experience, contemporary museums have transformed into experience-oriented, educational, interactive and inclusive spaces. To fully understand the reasons

Research Article - This article was checked by iThenticate 
and needs for these changes, concept of art, culture and museum experience in the $21^{\text {st }}$ Century have been examined through literature review along with field trips on contemporary art museums mainly in Europe throughout the author's Ph.D. thesis research. Due to the rapid developments in technology, electronic sources have also been used to acquire the latest updates on digital interactive experiences in contemporary art museums.

\title{
ART, CULTURE AND MUSEUM EXPERIENCE IN THE $21^{\text {st }}$ CENTURY
}

Production of artworks and media has been affected by technological changes throughout art history. Walter Benjamin reveals in his essay "The Work of Art in the Age of Mechanical Reproduction" (1935) the new meanings that may occur in the reproduction of art works, with the inclusion of photography and cinema in our lives. Benjamin begins with a quotation from the essay "The Conquest of Ubiquity" (1928), by Paul Valéry:

\begin{abstract}
"Our fine arts were developed, their types and uses were established, in times very different from the present, by men whose power of action upon things was insignificant in comparison with ours. But the amazing growth of our techniques, the adaptability and precision they have attained, the ideas and habits they are creating, make it a certainty that profound changes are impending in the ancient craft of the Beautiful. In all the arts there is a physical component which can no longer be considered or treated as it used to be, which cannot remain unaffected by our modern knowledge and power. For the last twenty years neither matter nor space nor time has been what it was from time immemorial. We must expect great innovations to transform the entire technique of the arts, thereby affecting artistic invention itself and perhaps even bring about an amazing change in our very notion of art."
\end{abstract}

As Valéry states here, using new techniques for creating and understanding the contemporary works of art are inevitable. Production methods change with new techniques, and this change also enables the production of artworks with the possibilities of technology. Each era has its own new but uninheritable potential to interpret the prophecies that the art of past ages conveyed to it (Doherty, 2009). This potential is the key to interpret the inherited with the new techniques.

Benjamin states that making reproduction within the technical possibilities causes significant changes in the meaning of artworks. For Benjamin, even though a copy does not have the uniqueness of the original and causes significant deficiencies in the work of art, a reproduced painting, with the help of technical possibilities, such as photography, motion picture, and recording, may have other positive features. According to Benjamin, this reproduction brings the work of art from stationary to portable, from uniqueness to mass distribution, and from autonomy to independence (Işılar, 2016). Thus, the artwork becomes accessible for public use and a part of a culture industry that can be produced over and over again with the new techniques of the current era.

As the art changes, the exhibition techniques and the museums change along with it. The contemporary culture industry imposes the new; in other words, the "popular". Despite the prediction that the 'new' has started to age from the moment of its emergence (Huyssen, 1999), returns of technology inevitably change and transform cultural spaces along with production and display methods. Considering that the concept of experience is directly related to acquiring knowledge and learning new things, it is possible to say that inclusive and interactive exhibitions and learning methods in museums transform the museum experience.

The increasing expectation to be entertained and interaction has created the concepts called 'experience economy' (Pine \& Gilmore, 1998) or the 'entertainment economy' (Wolf, 1999). As Pine \& Gilmore emphisizes, experience was always a part of the entertainment, now became the staging of a product to create a memorable experience (as cited in Erb \& Ong, 2018). Contemporary museums as entertainment centers, aim to attract visitors by presenting temporary exhibitions and additional

Research Article - This article was checked by iThenticate 
services other than galleries such as cinemas, concerts, workshops, restaurants etc. Accordingly, they are often designed as products that have the value of architectural representation. The transformation of museums into large-scale, iconic, impressive, interactive and experience-oriented structures can be attributed to the impact of a series of innovations. Similar to the representation methods, architectural spaces have also adapted to the new technologies of the era. Developments in production methods and material technologies allow the design of diverse shaped, sculptural structures. These gigantic-sized sculptures are not only observed but also create structural, functional spaces (Pallasmaa, 2011). Although creating iconic and striking museum structures have received many criticisms, it is possible to say that it has increased the interest in museums (Url-1). Similar situation can also be seen in contemporary artworks. While buildings are produced in sculptural forms, sculptures also appear as structures that can be experienced on large scales and they are articulated into the urban fabric.

Culture is a complex and abstract concept in which each of the human-social sciences has its definitions. It defines a universal condition of human existence by predicting thinking, imagination and the creation of meaning itself as a result of human activities (Christians \& Steiner, 2010). Cultural and artistic productions are the universal heritage elements of humanity as they deal with the universal values of humanity. Science and technology can likewise be developed with collective accumulation; regardless of the region they are produced. In this context, artistic activities, entertainment culture, and media types are intertwined in the $21^{\text {st }}$ century. The production, presentation, and consumption of culture and art objects can be supported by digital technologies. Today, digital artworks and performing arts are exhibited together. Moreover, there are museum spaces where architecture and artifacts are supported by virtual and augmented reality implementations.

Cultural institutions have become obliged to adapt to new technologies and to renew them by observing the expectations and needs of society through the sociological effects of technology. The increasing trend in the use of digital technologies in cultural activities can only be achieved through including users in the circulation. Although digital technology applications provide users with access to information in many ways, they can only gain meaning within the mental and intellectual structures of the users (Falk \& Dierking, 1992). Therefore, the culture industry has focused on user experienceoriented applications.

Experience is the way individuals know and perceive their surroundings through senses, perception, and comprehension (Tuan, 1977). It takes place within an ongoing timeframe with sensory and perceptual interaction of space. The experience changes with several factors such as the activated senses, the length of the experience, and the visitor's emotional state. In this context, the experience is both mental and physical activity. Senses not only create information in the mind but also trigger the imagination by creating new artistic ideas (Pallasmaa, 2011). Offering an educational social environment, museums operate as spaces where many multi-layered experiences address the senses. Today in contemporary art museums these experiences are supported by digital interactive technologies.

\section{DIGITAL INTERACTIVE TECHNOLOGIES IN CONTEMPORARY ART MUSEUMS}

The concept of interaction is defined by the Turkish Language Association as "to have a mutual influence". Digital interaction is realized through various digital interactive interfaces and humanmachine interaction. The concept of interactivity and interactive interfaces have adapted to daily life with the emergence and development of the communication technology called the Internet (Arabacioğlu, 2008; 2011; Arabacıoğlu \& Aytıs, 2016).

According to Parry (2013), the use of digital technologies in museums has become normative after the digital technological developments of the last decade. Interactive technologies have started to be used in museums in the 1920s with science museums in Europe. The participatory learning process was created with tangible objects. In 1933, the method of transferring information through interaction with

Research Article - This article was checked by iThenticate 
objects was extended to science museums in the United States (Bedno \& Bedno, 1999). High-tech interactive systems such as augmented reality, multi-touch surfaces, and virtual reality have been increasingly used in many art museums in recent years (Confalonieri, 2015).

Digital interactive technologies are sensory-oriented systems that eliminate the constraints arising from human ergonomics. These systems have an innovative approach. As a consequence, they offer unusual, interactive spatial experiences. Although static exhibition systems still maintain their place in museum spaces, a mixed exhibition system is being implemented. Interactive artworks or multilayered experiences can be provided. Virtual reality technologies assist to give information about the artworks and guidance in the exhibition space.

Commonly used technologies in contemporary museums can be classified under two headings as 'passive' interactive digital technologies and 'active' interactive digital technologies. Passive interactive digital technologies include projection mapping systems, sound systems, digital displays, and sensors. Interactive systems that require active participation are touch screens, QR code implementations, virtual reality, augmented reality, mixed reality, and artificial intelligence applications. It's possible to create an engaging atmosphere by using multiple interactive technologies at the same time.

\section{'Passive' Interactive Digital Technologies}

Passive interactive digital technologies are highly commonly used systems that create an indirect interaction with museum visitors such as sound systems, digital screens, and projection devices used in museum galleries.

\section{Digital screens}

These are the systems used to reflect various video or photographic images in contemporary art museums. Digital displays, often used in conjunction with sound systems, are technologies that interact with the viewer's perception of the projected images without requiring active participation.

Information transfer with digital display systems is widely used in contemporary art museums. Museums such as Museum of Art, Architecture, and Technology (MAAT) in Lisbon, the content is mainly digital so the museum offers digital screens of different sizes. Although this type of use changes according to the content and layout of the exhibition, it is observed that the use of digital displays varies according to the theme of the museum.

\section{Digital audio systems}

Digital audio systems are technologies used to record, store and process audio signals in digital format. Sound systems ensure the integrity of the meaning of the artworks, to construct the atmosphere of space or simply to transfer information. Digital audio systems can also be used together with digital displays and projectors. Laurent Grasso's artwork "The Horn Perspective" is an example of a digital audio system use in museums. At the exhibition called "Gravity: Imaging the Universe after Einstein" gigantic speakers were installed at MAXXI in Rome in 2018. The perception of space was changed with the visuals supported by various sounds.

\section{Projection mapping}

Projection devices are a widely used technology not only in museums but also in various places such as schools, offices, and residences. These devices work by projecting a digital image onto an object or a surface. It is one of the most common display methods in museums and often used to make video and light reflections to temporarily transform the atmosphere of the space.

Research Article - This article was checked by iThenticate 
Projection mapping is a concept that emerged in recent years. It allows creating reflections with instant light and video shows on any surface. It is widely used in the entertainment sector, especially in performing arts where the stage design changes frequently.

There are examples where historical events are revived by reflecting visuals on monuments. Such a visual projection technique was performed at the Roman Forum in Rome in 2018 (Url-2). The history of the forum is revived by moving visuals projected on the ruins by projection mapping. This practice is an important example of the use of technology to transfer information in ancient open-air museums.

Today, it is feasible to revive the cultural heritage destroyed as a result of natural disasters, wars or looting with digital representation methods. When the Bamyan Budha statues in Afghanistan were destroyed by the Taliban in 2001, 1500 years of world cultural heritage were destroyed. In May 2019, a 3D image of the sculpture was projected into the cave recess, where the demolished Budha statue was located. Thus, a project has been made in which the disappeared work is brought to life virtually. Similarly, Iranian artist Morehshin Allahyari has reproduced a 3D replica of the King Uthal statue destroyed by ISIS in 2015 in Iraq, by using CAD programs and a three-dimensional printer as part of the exhibition "Material Speculation". Of course, it is not possible to replace the destroyed artworks with their reproduction that does not contain the original pieces 'aura' and relations with the history. It can only be a reproduction. However, with the models created by combining the data gathered from the digital images of the art work, it is attainable to transfer these heritages to the future generations in detail and to analyze them in three dimensions. In terms of the culture transfer, this technique is a way of archiving.

Apart from projecting images to a point with a single projection device, another example we have seen in museums in recent years is the projection mapping by projecting images on all surfaces of the desired area by using multiple projectors. The perception of space can be completely altered using the comprehensive digital museum experiences created with various visuals, lights, and sounds. The immersive exhibitions such as "The Klimt's Nights", "Dreamed Japan, Images of the Floating World" and "Van Gogh, Starry Night"at the Atelier des Lumieres are some of the latest examples of projection mapping technique (Figure 1).

Projection mapping can transform into an interactive show with the help of technologies such as sensors, infrared tracking cameras, and multiple projectors. Sensors or infrared tracking cameras can be placed on suitable surfaces and react to weight, volume or ambient sound of the object according to the designed software. Similar digital interactive applications can be used in museum interiors to create 3D topographic maps or artistic installations.

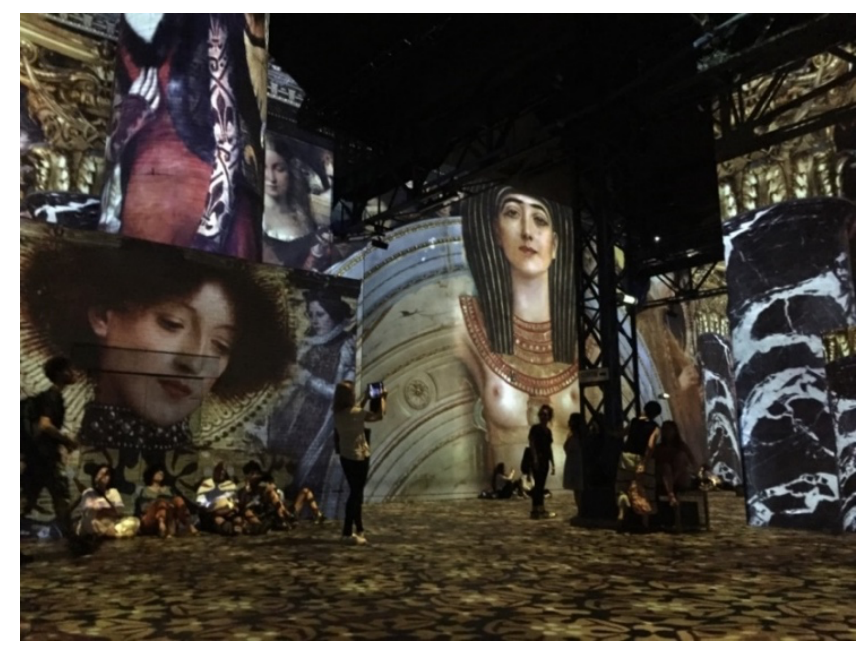

Figure 1: Projection mapping, "The Klimt's Nights" at Atelier des Lumieres, Paris. Source: Author.

Research Article - This article was checked by iThenticate

Copyright (C) The Turkish Online Journal of Design, Art and Communication 


\section{Sensors}

Sensors are systems that can process data by sensing pressure, light, heat, sound, and motion. The data generated by the sensors, in which the user interacts without active participation, provides an indirect interaction by transferring data to devices of various functions.

The use of sensors in museums can be realized both spatially and in artwork/user interaction. Motion sensitive sensors can be used for determining the number of visitors and mapping of visitor movements. Besides, sensors can be used in galleries to detect the movement of the visitors and be projected as an image on digital screens simultaneously. Depending on the visitor's movement, the image on the screen also moves and interacts with the visitors. It's an indirect interaction because whether the visitor is aware or not, they are involved in the projection.

Another example of the sensors used in museums is the alarm systems that activate by the movement. This creates an immaterial barrier between artworks and visitors. Thus, the visitors receive an automatic warning to move to an appropriate distance with the artwork.

\section{'Active' Interactive Digital Technologies}

These are digital interactive technologies that require the active participation of the museum visitor, where they interact directly and activate the content through their choices. These technologies can be categorized into six headings; touch screens, quick response codes, virtual reality, augmented reality, mixed reality, and artificial intelligence implementations.

\section{Touch screens}

Touch screens are digital displays with a panel sensitive to fingertips or suitable pens. The initial researches on touch screens began in the mid-1960s with IBM's research in Ottawa, Canada and the University of Illinois. In the 1970s, several different technologies were introduced, and in 1972 the PLATO IV touch screen system was introduced in selected primary schools (Buxton, 2010) (Figure 2).

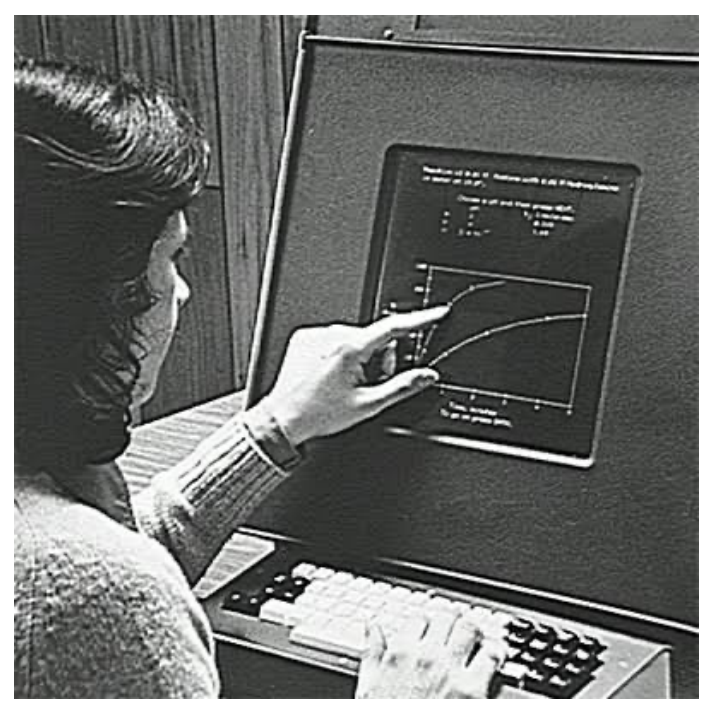

Figure 2: PLATO IV with touch screen and plasma panel display (1972), University of Illinois Archives, (Url-3).

Multi-touch systems were developed in the mid-1980s (Lee et al., 1985). It is still evolving today. Especially after the launch of Apple iPhone in 2007, people are accustomed to using touch screens in daily life.

Research Article - This article was checked by iThenticate 
Touch screen technology is used in museums through kiosks, information panels, and tablets. Before digital technologies, in case of any failure or need for correction on information boards, the process of design was extended with a redesign, printing, and application. With digital information boards, these operations can be performed in a much shorter time. In some museums, the exhibition catalog and the distribution of the exhibition layout according to the floors are presented with touch screens. As an interactive learning method, it is used for transferring information by gamification.

Some systems allow multiple users to interact with touch screens. It is possible to access the works in the museum collection digitally via touch screens and zoom in on the artworks' digital copies to get information, to play games and/or to watch videos, etc. "ArtLens Wall in the Cleveland Museum of Art is an example of such use. The 40-meter interactive, multi-touch touch screen display on the ArtLens Wall makes it available to view 4200 to 4500 artworks in the permanent collection of the museum in real-time. Besides, it provides thematic grouping. Visitors can also display light-sensitive artworks that must be stored in the archives. Furthermore, it also allows visitors to virtually "like" the artworks displayed on the ArtLens Wall through the ArtLens App and download the images of their favorite artwork to their devices via Bluetooth technology (Figure 3).

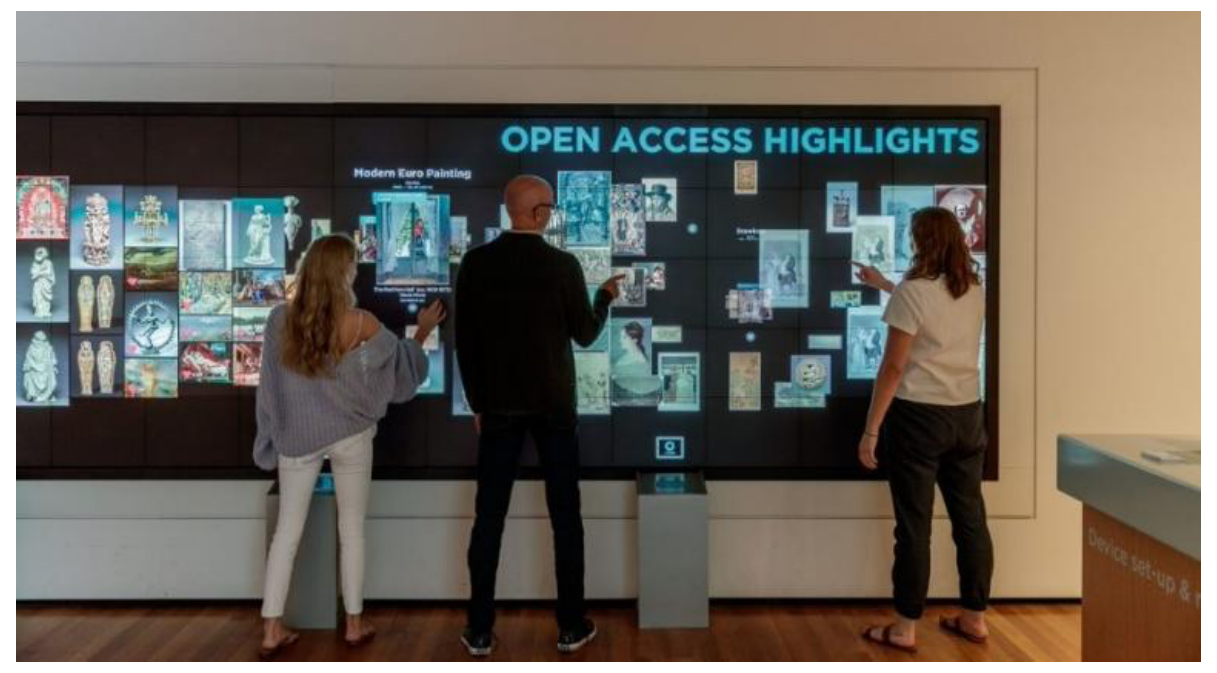

Figure 3: "ArtLens Wall", Cleveland Museum of Art, (Url-4).

\section{Quick response (QR) codes}

QR codes are pointers that redirect users to the specified application or data when detected by digital devices. It is a widely used method in terms of accessibility and frequency of use among interactive technologies. It is easy to manufacture and access. Digital media can be attached to static objects used in everyday life with a simple label by using QR codes.

The use of QR codes in museums is often added to the name tags of works of art and directs visitors to the online resource for detailed information about the work. Thus, the rate of informative writings in the museum interior is reduced and visual integrity is ensured. Information can be transmitted to the visitors with only a small pointer by reducing the distributing factors around the works of art. Moreover, access to this data is at the visitor's preference.

Another method of using QR code in museums is to create an alternative, fun museum experience through museums' smartphone/tablet applications. In 2014, the Barcelona Museum of Contemporary Art affixed QR codes to different places and surfaces within the museum, which could be activated by using the museum's digital application "MacbaAPP". It was aimed for the visitors to activate the QR codes in the museum using the camera in the application and to access short videos about the curation process of the exhibited artworks. Visitors aiming to find QR codes using the application are involved

Submit Date: 05.07.2020, Acceptance Date: 18.08.2020, DOI NO: 10.7456/11004100/007

Research Article - This article was checked by iThenticate

Copyright (C) The Turkish Online Journal of Design, Art and Communication 
in a fun and educational game where they can have an alternative museum experience (Karayılanoğlu, 2019) (Figure 4).

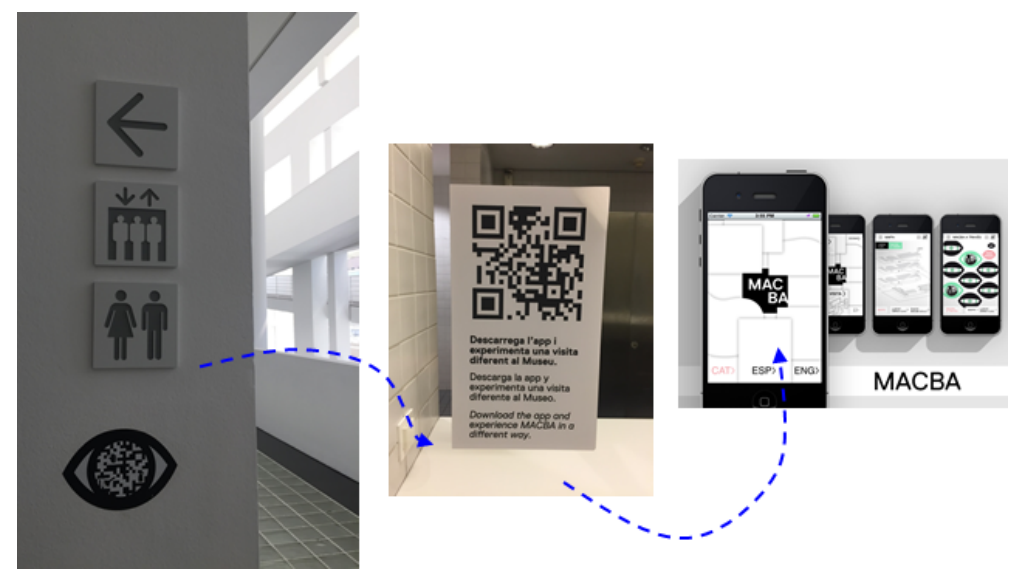

Figure 4: QR codes and MacbaAPP at Barcelona Museum of Contemporary Art, Source: Author \& (Url-5).

Nowadays, smart phones can detect QR codes with their builtin cameras. This allows access to information within seconds. Its production and application are low cost and convenient. Therefore it is widely used in many museums.

\section{Virtual reality (VR)}

The idea of virtual reality was first introduced in 1965 by the American electrical engineer and computer scientist Ivan E. Sutherland (Mazuryk \& Gervautz, 1999). In his article The Ultimate Display, he predicts the basis for today's emerging virtual reality (VR) technologies. According to Sutherland; instead of thinking about the computer screen as a way of showing information, it should be thought of as a window of a virtual world that can "look like real, sound like real, act like real, interact like real, and feel like real". In addition to devices sensitive to hand and arm movements, he also mentioned that systems capable of reacting to the movements of the eye and interacting with other senses can be improved (Sutherland, 1965). The first head-mounted display (HMD) "The Sword of Damocles" was also designed by Sutherland (Mazuryk \& Gervautz, 1999). In the last 55 years, computer graphics and virtual reality applications have considerably enhanced the level of graphic realism.

Virtual reality is a system in the advanced stages of its development, with other reality systems such as augmented reality and mixed reality. It is an immersive system that isolates the user from the real world by creating a virtual reality environment. It enables you to experience a computer-generated virtual environment through HMD. With the development of extremely powerful, cost-effective VR devices such as Samsung Gear or Oculus Rift, their use is becoming public and commercially available. (Jung et al., 2016). Today, there are VR glasses developed by different technology companies such as Oculus Rift S, Oculus Quest, HTC Vive Pro, Playstation VR. It is used in various fields such as education, art, video games, architecture, and health.

The use of VR in museums is varied. It is used as a tool for restoration projects, as well as in cultural heritage sites with restricted access due to conservation. Because it is interactive and fun, it is particularly common in science museums (Carrozzino \& Bergamasco, 2010). VR tours at the Nikola Tesla Museum in Serbia is an example. Tesla's life is described in an inclusive and immersive virtual experience through VR glasses (Url-6).

As well as science museums, today, VR implementations are also used in collection museums to create interaction with artworks of limited access. The study "The Museum of Pure Form" (Loscos et

Research Article - This article was checked by iThenticate 
al., 2004), has been developed as a system that enables artworks to be touched in a virtual environment. 3D models can be examined with VR glasses and a two-point-contact haptic device. Tactile devices are still being developed and used together with VR glasses. In addition to the sense of tactile perception, it is also feasible to move objects and change forms in a VR environment.

In contemporary art museums, virtual reality applications are mostly seen as new media art. In addition to experiencing a completely imaginative environment, VR environments are made in which the existing environments can be modeled and analyzed in detail.

\section{Augmented reality (AR)}

Augmented reality, unlike virtual reality, is the projection of a digital image into a real environment. Although it is a much-advanced concept than VR, it is still in the progress of development in parallel with VR researches. Ronald Azuma described the concept of augmented reality (AR) and its characteristics in his extensive research in 1997 (Gülel \& Arabacioğlu, 2019). In his study, Azuma mentions three basic systems that differentiate AR from VR; scene generator, a display device, tracking device and tracking and sensing. Today, AR applications can easily be used by electronic devices such as mobile phones and digital tablets which are widely used in daily life. Especially in 2016, augmented reality applications have become globally widespread with the location-based, multiplayer, online augmented reality game "Pokemon Go. There have been studies that observed increased physical activity of the users of the application (Althoff et al., 2016). It is used in the fields of education, health, advertising, entertainment, sports, architecture, archeology, and museology, etc.

The use of AR technology in museums is increasing. Catalan architect Antoni Gaudi's masterpiece Casa Batllo in Barcelona is one of the museums in which the place is exhibited as an exhibition element. With the AR system, which perceives a model of Casa Batllo as a pointer, virtual and moving visuals representing the old state of the place can be seen in real-time (Kılıç, 2016). In this way, possible damage to the exhibition space with various text and visual additions is prevented. The visitors can see both the old and the present state of the building simultaneously.

AR technology is also used in art museums. The Salvador Dali Museum, an art museum in the USA, used AR technology in "Visual Magic: Dalí's Masterworks in Augmented Reality" exhibition held in 2019. Through the exhibition, Dali's works can be viewed in real-time by downloading the application called "The Dali Museum". With this experience, users interact and learn about the symbolic meanings and references in Dali's artworks.

Another example of augmented reality implementation is produced by the Tate Britain Museum in 2019 created for Instagram in collaboration with Facebook. By using AR, selected artworks with extraordinary stories are displayed in motion. Visitors using the camera in Instagram application scan Tate's Instagram name tag to activate the experience, and receive a welcome message and a map to help them navigate to each of the eight AR-supported images. The application then animates the story for each painting on the user's viewing device (Figure 5).

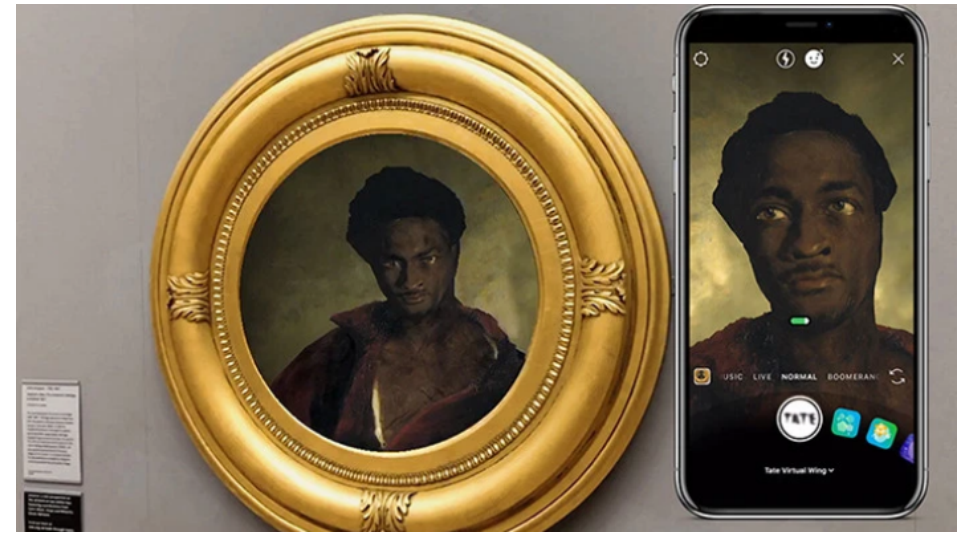

Research Article - This article was checked by iThenticate

Copyright (C) The Turkish Online Journal of Design, Art and Communication 


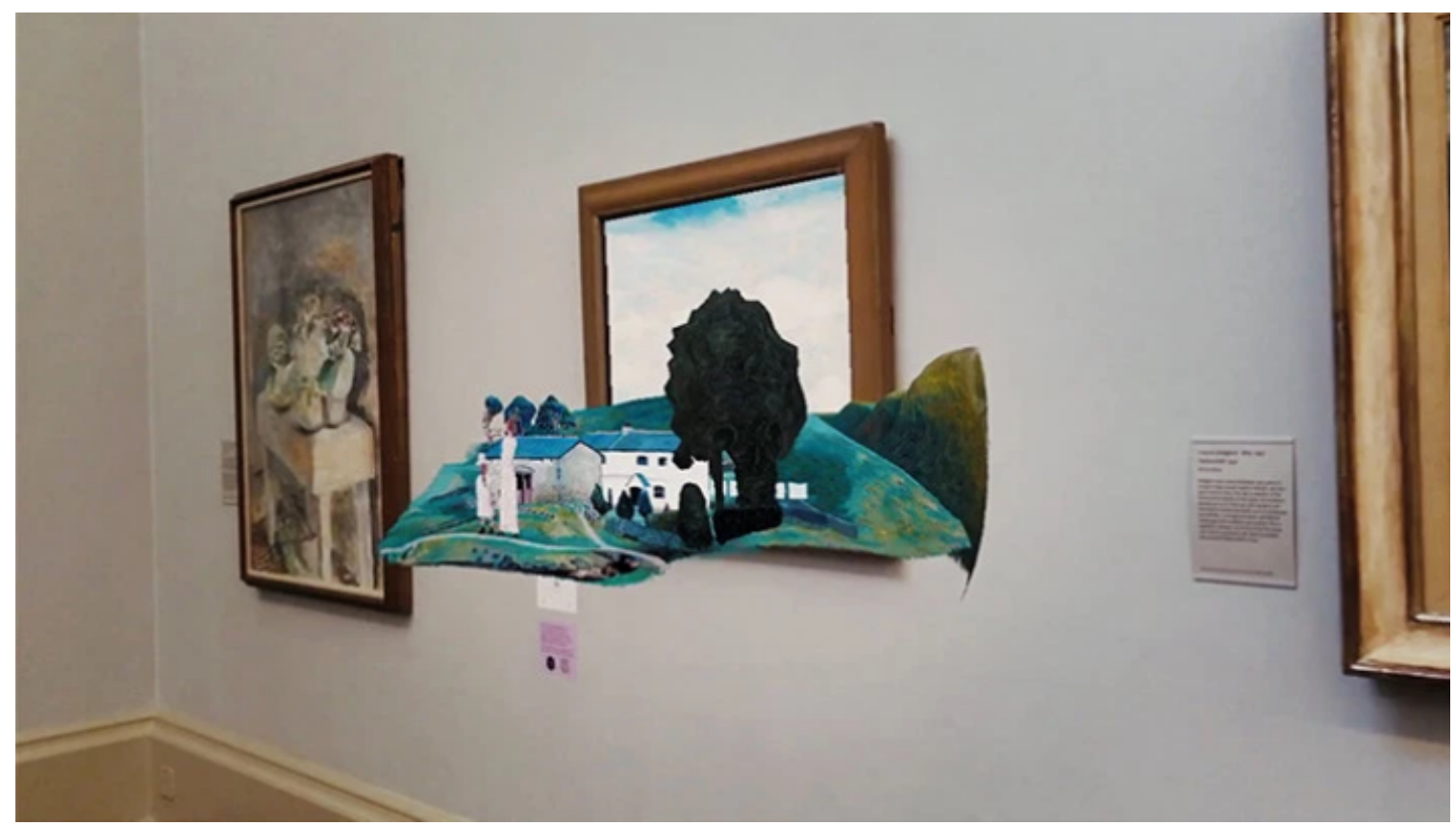

Figure 5: AR implementations in Tate Britain, London, UK, (Url-7).

It is seen that AR technology is a system that increases and improves both spatial and artistic interaction in art museums. In this context, it can be seen that as augmented reality technologies develop, its use in museums will increase.

\section{Mixed reality (MR)}

Mixed reality is the combination of AR and VR technologies in a single interface. The concept was first described by Milgram and Kishino in 1994 with two new terms called mixed reality (MR) and augmented virtuality (AV). Milgram and Kishino discussed a concept in which virtual and augmented reality are in the same visual environment (Figure 6). Accordingly, augmented reality technologies are implemented in two ways in real space. The first is through portable AR technologies such as smartphones and tablets or wearable devices like VR glasses. Here, virtual objects are overlapped in the real space. In the second method, the perception of augmented reality is intensified by the virtual image projected to the physical space by applications such as projection mapping (Raskar et al., 1998). It is illustrated by Milgram and Kishino's diagram of reality and virtuality, which describes the relationship between augmented reality and augmented virtuality to the real environment and the virtual environment.

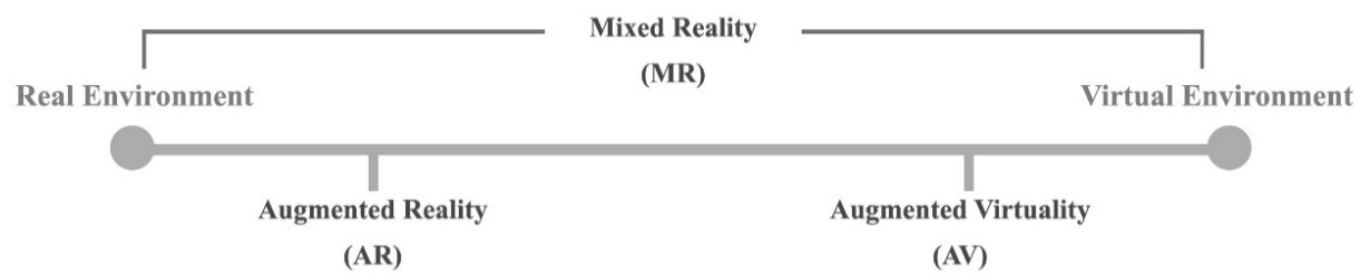

Figure 6: Reality-Virtuality (RV) Continuum (Milgram \& Kishino, 1994).

Accordingly, while the virtual environment defines a world where only synthetic data exists, the concept of AR is formed by the overlap of the information generated by the computer with the spaces

Research Article - This article was checked by iThenticate

Copyright (C) The Turkish Online Journal of Design, Art and Communication 
or objects in the real environment. The concept of $\mathrm{AV}$ is located closer to the virtual environment (K1lı̧, 2016).

The idea of using digital and the real together is not a new concept for museums (Galani, 2003). MR has various uses in contemporary museums. VR interfaces and devices provide diversity to rapidly develop and enhance interaction in museums. Many interactive devices can be used with applications that can be renewed sustainably through computers (White et al., 2007). HoloLens 2.0, a secondgeneration virtual reality set, introduced by the software company Microsoft in 2019, can create a 3-D spatial perception with its high-resolution spiral imaging system. It has an 8-megapixel tracking sensor and it also allows us to interact with hologram contents with the support of artificial intelligence (Url8). The operating principle of HoloLens is as follows: It creates a real-time 3D grid by detecting the real environment in with the built on cameras and sensors. This grid continues to be updated by scanning the space as the user moves. The holographic images placed in the real space can be viewed within a 360-degree viewing angle.

In 2018, a mixed reality museum named "MR Museum Kyoto" was established in Japan within the scope of the "Hakuhudo-VRAR" project. In this mixed reality museum, viewers use the Microsoft HoloLens MR set to experience a 10-minute MR experience supported by 3-D graphics while standing in front of the traditional 400-year old masterpiece on display. During this experience, a holographic image of a well-informed Kennin-Ji monk is guiding the tour (Url-9). Visitors experience the works with a graphical narrative of an eternal universe and a lush world depiction under a rainstorm with lightning and thunder. Thus, works of art are presented in detail both with the narration of a historical figure under the context of the artwork and with an immersive experience provided by $3-\mathrm{D}$ visuals.

Studies have been conducted using Microsoft HoloLens in mixed reality experiences in museums. Within the framework of a study carried out by the University of Campania in Italy, various interactive experiences such as virtual captions, the in-depth sound system performed by professional actors, holographic images, animated 3D models, and interactive games have been implemented (Url10). By using MR, digital interactive guided tour can be held in museums.

\section{Artificial intelligence (AI)}

Artificial Intelligence is a sub-section of computer science that includes studies on the ability of computers to create intelligent behavioral programming and behavioral data algorithms (Newell, 1980). In his study "Computing Machinery and Intelligence" in 1950, Alan Turing made arguments about whether machines can think (Turing, 1950). Today, artificial intelligence (AI) is used in so many different fields such as psychology, robotics, architecture, medical industry, the entertainment industry, and the defense industry. As the studies continue, the outcomes of artificial intelligence become much more realistic. With the machine learning systems, machines can develop simultaneously in line with the data they receive without the need for new programming with each process. Such as digital voice assistants of Apple's Siri and Amazon's Alexa are artificial intelligence applications that are involved in daily life and are widely used.

According to the American Alliance of Museum, artificial intelligence is trending in museums (Url11). AI-based digital tour guide robots interact with visitors and offer suggestions to improve the museum experience based on the data they receive. A robot named "Berenson" was developed by robotics engineer Philippe Gaussier and anthropologist Denis Vidal in 2011. In 2016, in an exhibition held at the Quai Branly Museum in Paris, Berenson collected the reactions of the museum visitors to the artworks and directed this data to a computer whether the visitors like or dislike the artworks. $\mathrm{He}$ categorized the reactions in two if the reaction is positive it is defined with a green ring and if negative, it is defined with a red ring. Accordingly, Berenson received data between 10-20 visitors every day and reacted smilingly to the artworks which he described as positive. (Url-12).

Research Article - This article was checked by iThenticate 
In the exhibition called "Dali Lives" at the Dali Museum in Florida, USA, in 2019, visitors were able to communicate with Salvador Dali through a digital display using artificial intelligence technology. It was an AI application that can simulate Dali in real-time, in which 6000 images from Dali's videos are visualized through a software. Visitors can activate the system by pushing a button on the digital display and communicate with a "deep fake" Dali that generates a dialogue comprising a different combination each time. The exhibition creates a fun and realistic artificial intelligence experience. At the end of the experience, also a selfie is taken by the artificial Salvador Dali and sent to visitors' emails (Figure 7).

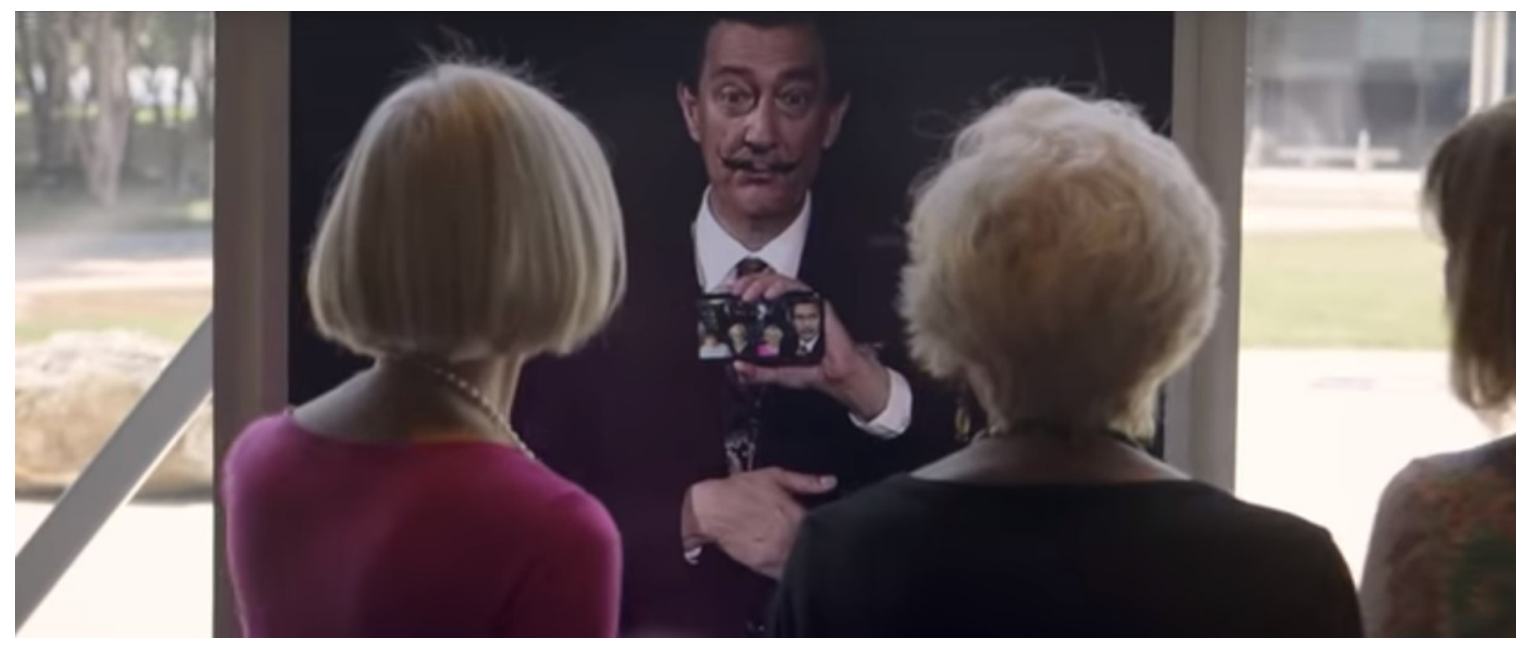

Figure 7: "Dali Lives" exhibition. Screenshot from the video "Behind the scenes: Dali Lives" (Url$13)$.

Google's digital app "Arts \& Culture" offers an artificial intelligence application called "Art \& Selfie" where the users are matched with their identicals in art history. With such applications, it is ensured that art is spread to a wide audience with fun-learning techniques.

AI is used in the production of artworks, as well as realistic machine-human interaction. In 2017, in 'The Next Rembrandt' project, 348 works of Rembrandt were scanned in 3D and digitilized using the deep learning algorithm. Rembrandt's artistic style was imitated with the facial recognition technique. As a result of the study, a new Rembrandt work was obtained by imitating the geometric forms used by the painter, brush strokes and the use of light and shadow. The artwork, which is a completely artificial intelligence product, was produced using a 3D printer (Url-14).

After IBM's AI chess computer Deep Blue defeated the world chess champion, Garry Kasparov, in 1996, there has been a debate over the possibility that machines can learn and acquire "artificial consciousness". Although it is not yet possible for machines working with various algorithms to gain autonomous consciousness, it is still an exciting idea in the scientific world.

With the use of artificial intelligence systems capable of fully interpreting data, visuals, and information of the museum collections and accessing the internet resources simultaneously, the museum experience can be rapidly updated and personalized based on rational data. In the future of museums, there may be AI curators who curate exhibitions by combining the average data collected from the visitors and the chronological, artistic and aesthetic qualities of the works.

\section{CONCLUSION}

21st Century museology supports participation by emphasizing communication. Contemporary art museums aim to offer multiple and interactive information sharing instead of one-sided information transfer. In this paper, it was aimed to examine and point out the effects on multiple information

Research Article - This article was checked by iThenticate

Copyright (C) The Turkish Online Journal of Design, Art and Communication 
sharing with the current digital interactive technologies used in contemporary art museums. The use of digital technologies in museums is inevitable after the digital technological developments of the last decade.

Digital interactive technologies are based on human senses and can eliminate restrictions from human ergonomics by alternative methods. They offer unusual spatial experiences due to their innovative approach. Experiencing digital interactive technologies in museums is realized by perceiving the works exhibited by users with the help of various digital interfaces. They radically change the museum experience in that they allow the user to shape their own experience and provide flexible and alternative experiences. Static exhibition systems still maintain their place in museums, but a mixed exhibition system including new technologies is implemented.

Thanks to new technologies, there are examples where works of art can be transformed / designed simultaneously with interactive systems. Multi-layered experiences that can be accessed by using augmented reality applications can be offered.

Contemporary art museums integrate complementary digital technologies that can interact with the human senses to increase the experience and facilitate the information transfer. Creating a fun, interactive and educational environment that stimulate the senses to increase the experience.

Touch screens, projection devices, QR code implementations are commonly used in daily life. VR, AR, MR, AI systems also have the potential to be as such. Virtual, augmented, and mixed reality applications have not yet reached the level of graphical quality of Sutherland's vision. However, studies in this area are still in progress and the devices are offering much more realistic results day by day.

By using projection mapping, museum spaces can be perceived differently than they are, and create dynamic spaces that can change and transform rapidly. In addition to this, immersive digital exhibition experiences can be created with moving visuals reflected on all surfaces of the space.

AR works with the principle of reflecting virtual visuals into the real space. It is a technology that has lots of potential purposes of use in the museums that can be easily operated with smartphones, digital tablets. The use of AR can increase the museum experience and facilitate access to information without isolating the visitor from the real space. With AR technology, static artwork are presented as dynamic and interactive displays. This meets the factors that increase the museum experience such as entertainment, engagement with multiple senses, escaping reality, and educating.

By using VR, artworks that are detached from their context by being taken in a museum can be presented with an immersive experience in their own stories and contexts.

AI systems can fully control the data, visuals, and information of the museum collections, and simultaneously access the internet resources and interpret the information instantly. Museum visits can become rapidly updated and personalized based on rational data. Exhibitions can be curated by AI curators that organize the exhibitions by combining the average data received from the visitors and the chronological, artistic and aesthetic qualities of the artworks.

Digital devices can interact with each other and visitors over the internet and solve problems that may occur during the exhibition process with instant solutions. Thus, in the long run, time and materials can be saved.

Therefore, it is seen that technological developments reflect artistic production and presentation techniques simultaneously. Although the uniqueness of digitally reproduced artworks is a subject of discussion, digital technologies are the key solution in terms of making art available to large masses and making museums inclusive. In this context, the importance of the use of the current technologies in the transfer of culture and contemporary art museums is evident.

Research Article - This article was checked by iThenticate 


\section{REFERENCES}

Althoff, T. \& White, RW \& Horvitz, E. (2016). Influence of Pokémon Go on Physical Activity: Study and Implications, $J$ Med Internet Res 2016;18(12):e315, doi: 10.2196/jmir.6759.

Arabacığlu, B.C. (2008). 'Etkileşimli Mekan' Tasarımı, KMIM Mimarlar Odası Kocaeli Şubesi Dergisi, 3, 43-51.

Arabacioglu, B.C. (2011). Interactive Space Design: The New Architectural Design Thinking by Using Intelligent Building Systems in Interior Spaces. VDM Publishing.

Arabacıŏlu, B.C. \& Aytıs, S. (2016). Bilgi-İletişim Teknolojileri Destekli Etkileşimli Mekân Tasarımı Süreci, Megaron 2016 Cilt Vol. 11 - Sayı No. 2, Istanbul.

Bedford, L. (2014). The Art of Museum Exhibitions : How Story and Imagination Create Aesthetic Experiences. Walnut Creek: Routledge.

Bedno, J \& Bedno, E. (1999). Museum Exhibitions: Past Imperfect, Future Tense, Museum News The American Association of Museums, September/October 1999, 4.

Benjamin, W. (2013). Pasajlar, Istanbul: Yapı Kredi Yayınları.

Benjamin, W. (1935). The Work of Art in the Age of Mechanical Reproduction, 2008, Penguin.

Black, G. (2012). The Engaging Museum : Developing Museums for Visitor Involvement. Hoboken: Routledge.

Black M. \& Hein, G. E. (2003). You're Taking Us Where? Reaction and Response to a Guided Art Museum Fieldtrip, in M. Xanthoudaki, L. Tickle \& V. Sekules (eds.) Researching Visual Arts Education in Museums and Galleries, Dordrecht: Kluwer Publishers.

Buxton, B. (2010). A Touching Story: A Personal Perspective on the History of Touch Interfaces Past and Future, Society, Information Display International Symposium Digest of Technical Papers, SID 10 Digest, 444, ISSN 0097-966X/10/4101-0444-\$1.00.

Carrozzino, M. \& Bergamasco, M. (2010). Beyond Virtual Museums: Experience Immersive Virtual Reality in Real Museums. Journal of Cultural Heritage, 11(4), 452-458.

Chang, E. (2006). Interactive Experiences and Contextual Learning in Museums, Studies in Art Education A Journal of Issues and Research 2006,47(2), 170-186.

Christians, C. \& Steiner, L. (2010). Key Concepts in Critical Cultural Studies, University of Illinois Press.

Confalonieri, R. \& Yee-King M. \& Hazelden K. \& D'Inverno M., Jonge \& D., Osman, N. \& Sierra, C. \& Agmoud L. \& Prade, H. (2015). Engineering Multiuser Museum Interactives For Shared Cultural Experiences, Engineering Applications of Artificial Intelligence 46 (2015)180-195.

Di Giuseppantonio Di Franco, P., Camporesi, C., Galeazzi, F., Kallmann, M. (2015) 3D Printing and Immersive Visualization for Improved Perception of Ancient Artifacts, Presence, Vol. 24, No. 3, Summer 2015, 243-264 doi:10.1162/PRES_a_00229, Massachusetts Institute of Technology.

Doherty, B. (2009). Between the Artwork and its 'Actualization': a Footnote to Art History in Benjamin's ‘Work of Art' Essay, Paragraph 32:3 (2009) 331-358 DOI:

10.3366/E0264833409000637.

Erb, M. \& Ong, C. (Ed.). (2018). Theming Asia: Culture, Nature and Heritage in a Transforming Environment, New York: Routledge.

Falk, J. H. \& Dierking, L. D. (1992). The Museum Experience, Washington D.C., Whalesback books, 113. 
Falk, J. H. \& Dierking, L. D. (2000). Learning from Museums: Visitor Experiences and the Making of Meaning, Altamira Press.

Falk, J. H. \& Dierking, L. D. (2012). The Museum Experience Revisited. Walnut Creek: Routledge.

Fouseki, K. \& Vacharopoulou, K. (2013). Digital Museum Collections and Social Media: Ethical Considerations of Ownership and Use, Journal of Conservation and Museum Studies, 11(1), Art. 5. DOI: http://doi.org/10.5334/jcms.1021209.

Galani, A. (2003). Mixed Reality Museum Visits: Using new technologies to support co-visiting for local and remote visitors, Museological Review. Leicester: Department of Museum Studies, Issue 10, $1-15$.

Gülel, Z. \& Arabacıoğlu, B.C. (2019). Arttırılmış Gerçekliğin (AG) Mekan Tasarımı Eğitiminde Kullanımına Potansiyeller ve Kısıtlamalar Işı̆̆ında Güncel Bir Bakış. STD 2019 Haziran -E-ISSN 2149-6595, S: 151-177.

Hooper-Greenhill, E. (1999). The Educational Role of the Museum. London: Routledge.

Hooper-Greenhill, E. (2000). Changing values in the art museum: Rethinking communication and learning. International Journal of Heritage Studies 6:1, pp. 9-31, DOI: 10.1080/135272500363715.

Hooper-Greenhill, E. (2007). Museums and Education Purpose, Pedagogy, Performance. London: Routledge.

Hooper-Greenhill, E. (Ed.). (2010). Changing Values in The Art Museum: Rethinking Communication and Learning. International Journal of Heritage Studies, 6(1), 9-31. DOI: 10.1080/135272500363715.

Huyssen, A. (1999). Alacakaranlık Anıları: Bellek Yitimi Kültüründe Zamanı Belirlemek, Metis Yayınlar1, Istanbul.

Işıklar, G. (2016). Paris Pasajlarında Bir "Flaneur" Walter Benjamin Sanat Yapıtı - Aura ve Lüks İmgesi, The Turkish Online Journal of Design, Art and Communication - TOJDAC, October 2016 Volume 6 Issue 4, DOI: 10.7456/10604100/006.

Jung, T. \& Dieck, M. C. \& Lee, H. \& Chung, N. (2016). Effects of Virtual Reality and Augmented Reality on Visitor Experiences in Museum, In Inversini, A. and Schegg, R. (eds), Information and Communication Technologies in Tourism, Springer International Publishing, Wien, New York, pp. 621-635 DOI: 10.1007/978-3-319-28231-2-45.

Kaminsky, J. (1957). Dewey's Concept of an Experience, International Phenomenological Society, Philosophy and Phenomenological Research, Vol. 17, No. 3 (Mar., 1957), pp. 316-330.

Karayılanoğlu, G. (2019). Digital Transformation in Contemporary Art Museums with The Example of Barcelona Museum of Contemporary Art. 5th International Conference on New Trends in Architecture and Interior Design April 26 - 28, 2019, Istanbul, Turkey.

Karayılanoğlu, G. \& Arabacioglu, B. (2017). Integration of New Visual Technology Experiences into Museum Interiors. Conference: 3rd International Conference on New Trends in Architecture and Interior Design, Helsinki, Finland.

Kılıç, T. (2016). Artırılmış Gerçeklik Teknolojisinin İç Mekân Tasarım Sürecinde Kullanılması, [Master's Thesis], Institute of Science, Mimar Sinan Fine Arts University, Istanbul.

Lee, S.K. \& Buxton, W. \& Smith, K.C. (1985). A multi-touch three dimensional touch-sensitive tablet, Proceedings of the ACM Conference on Human Factors in Computing Systems (CHI'85), pp. 21-27.

Loscos, C. \& Tecchia, F. \& Frisoli, A. \& Carrozzino, M. \& Ritter Widenfeld, H. \& Swapp D., Bergamasco, M. (2004). The Museum of Pure Form: Touching Real Statues in An Immersive Virtual Museum. The 5th International Symposium on Virtual Reality, Archaeology and Cultural Heritage Vast. 
Milgram, P. \& Kishino, F. (1994). A Taxonomy Of Mixed Reality Visual Displays. IEICE Transactions on Information Systems, Vol E77-D, No.12 December 1994. 2.

Moss, M. S. \& Endicott-Popovsky, B. \& Dupuis, M. J. (2015). Is Digital Different? : How Information Creation, Capture, Preservation and Discovery Are Being Transformed. London: Facet Publishing.

Pallasmaa, J. (2011). The Embodied Image Imagination and Imaginery in Architecture, John Wiley \& Sons Ltd. Publication, West Sussex.

Pine, B. J. \& Gilmore, J.H. (1998). Welcome to the Experience Economy. Harvard Business Review, 76(4), pp. 97-105.

Raskar, R. \& Welch, G. \& Fuchs, H. (1998). Spatially augmented reality. In Proceedings of the 1st IEEE Workshop on Augmented Reality (IWAR '98): Placing Artificial Objects in Real Scenes, pp. 6372.

Sutherland, I. E. (1965). The Ultimate Display. Proceedings of IFIP Congress 2, pp. 506-509.

Tribe, M. \& Jana, R. (2009) New Media Art, Taschen, pp. 12-13.

Tuan, Y. F. (1977). Space and Place: The Perspective of Experience, University of Minnesota Press, Minneapolis, London.

Turing, A. M. (1950). Computing Machinery And Intelligence. Computing Machinery and Intelligence. Mind 49, pp. 433-460.

White, M. \& Panagiotis, P. \& Liarokapis, F. (2007). Multimodal Mixed Reality Interfaces for Visualizing Digital Heritage. International Journal of Architectural Computing · June 2007 doi: 10.1260/1478-0771.5.2.32.

Wolf, M. (1999). The Entertainment Economy: How Mega-Media Forces Are Transforming Our Lives. London: Random House.

\section{ELECTRONIC SOURCES}

Url-1: https://www.architectmagazine.com/design/culture/in-defense-of-architectural-spectacle_o (Access date: 04.03.2019).

Url-2: https://business.panasonic.co.uk/visual-system/the-forum-of-augustus (Access date: 03.01.2019).

Url-3: https://archives.library.illinois.edu/erec/University\%20Archives/1505050 BrownBag/BBPlatoIV.htm. (Access date: 28.09.2019).

Url-4: http://www.clevelandart.org/artlens-gallery/artlens-wall (Access date: 28.09.2019).

Url-5: http://www.etnavilallonga.com/portfolio_detail.php?n=27 (Access date: 28.09.2019).

Url-6: https://nikolateslamuseum.org/en/vr-tours/ (Access date: 28.09.2019).

Url-7: https://tech.fb.com/augmenting-abstraction-facebook-expands-ar-experiences-with-tate-britain/ (Access date: 16.10.2019).

Url-8:https://www.webtekno.com/microsoft-karma-gerceklik-seti-hololens-2-fiyati-ozelliklerih63821.html (Access date: 16.10.2019).

Url-9:https://news.microsoft.com/apac/features/mixed-reality-museum-kyoto-unique-insightcenturies-old-japanese-artwork/ (Access date: 17.10.2019).

Url-10: https://mspoweruser.com/company-offers-bespoke-mixed-reality-museum-tour-solutionusing-the-microsoft-hololens/ (Access date: 16.10.2019).

Url-11: https://www.aam-us.org/2017/05/01/artificial-intelligence-the-rise-of-the-intelligent-machine/ (Access date: 17.10.2019). 
The Turkish Online Journal of Design, Art and Communication - TOJDAC

ISSN: 2146-5193, October 2020 Volume 10 Issue 4, p.423-440

Url-12: https://www.businessinsider.com/berenson-robot-critiques-art-at-paris-museum-2016-2 (Access date: 17.10.2019).

Url-13: https://www.youtube.com/watch?v=BIDaxl4xqJ4 (Access date: 17.10.2019).

Url-14: https://www.nextrembrandt.com/ (Access date: 17.10.2019). 